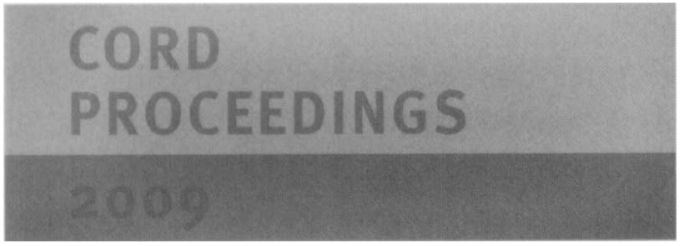

https://doi.org/10.1017/S2049125500000807 Published online by Cambridge University Press 
Dancing across Borders:

Danzas y Bailes Mexicanos

EDITED BY OLGA NÁJERA-RAMÍREZ, NORMA E.

CANTÚ, AND BRENDA M. ROMERO

432 pp. Illus. 2009. Unjacketed Cloth 978-0.252-03409.1 $\$ 80.00$.

Paper 978-0-252-07609-1. $\$ 30.00$

"This stimulating collection expands our understanding of

Mexican dance's significance by employing dance as a prism

through which to view broader sociocultural issues and mean-

ing. It sets a new standard for anthropological dance studies far

beyond its U.S.Mexico focus." - Daniel Sheehy, author of Mariachi Music in America: Experiencing Music, Expressing Culture
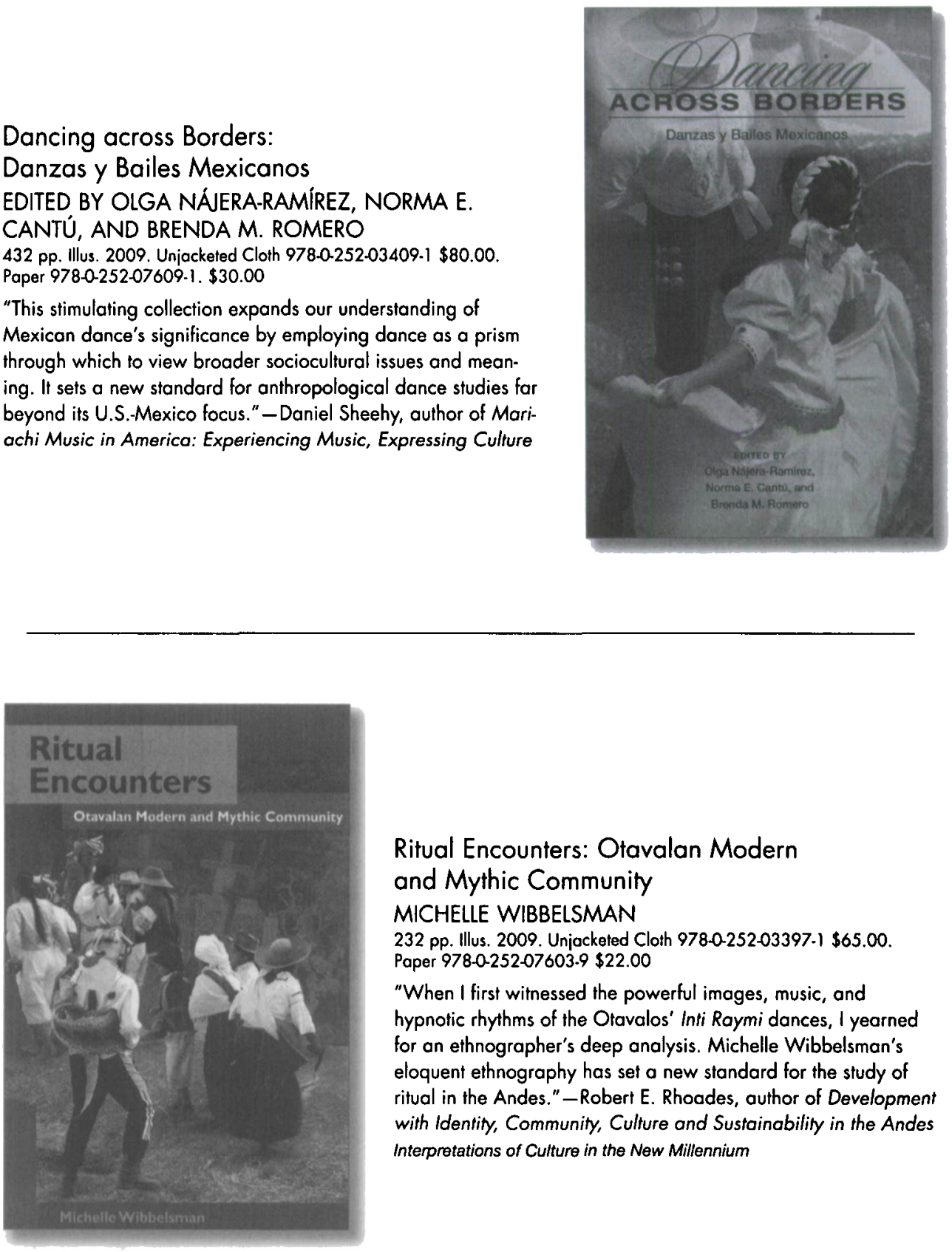

Ritual Encounters: Otavalan Modern and Mythic Community MICHELLE WIBBELSMAN

232 pp. Illus. 2009. Unjocketed Cloth 978-0.252-03397.1 \$65.00. Paper $978-0.252-07603.9 \$ 22.00$

"When I first witnessed the powerful images, music, and hypnotic rhythms of the Otavalos' Inti Raymi dances, I yearned for an ethnographer's deep analysis. Michelle Wibbelsman's eloquent ethnography has set a new standard for the study of ritual in the Andes." - Robert E. Rhoades, author of Development with Identity, Community, Culture and Sustainability in the Andes Interpretations of Culture in the New Millennium 


\section{UNIVERSITY OF ILLINOIS PRESS}

The Body Eclectic

Evolving Practices in Dance Training

Edited by MELANIE BALES and REBECCA NETLLFIOL

"Rich with anecdotes and a treasure trove of citations and references, this book will give dance teachers, scholars, graduate students, and dancers o fascinating read." - Dance Magazine Cloth $\$ 70$ 00; Paper $\$ 30.00$
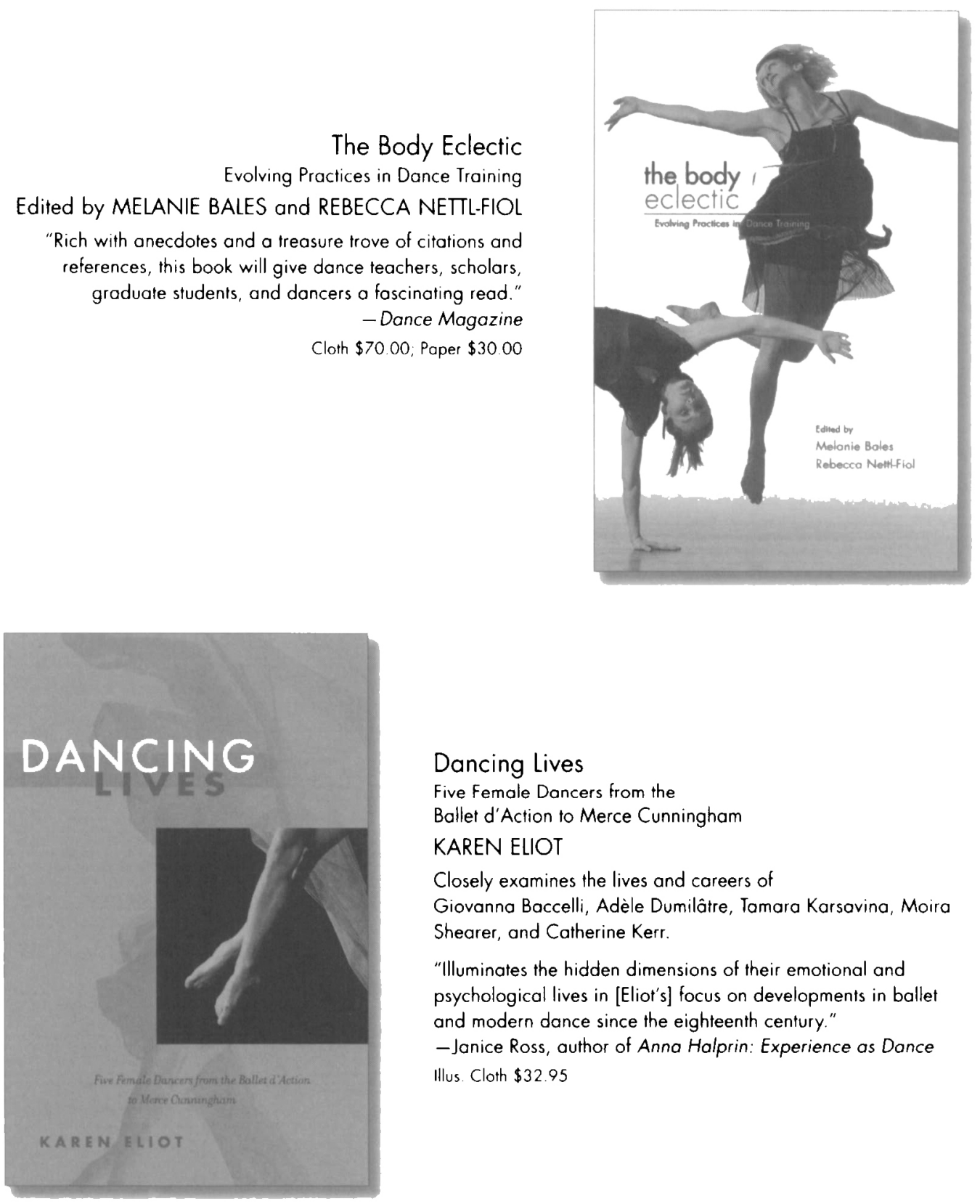

Dancing lives

Five Female Dancers from the Ballet d'Action to Merce Cunningham KAREN ELIOT

Closely examines the lives and careers of

Giovanna Baccelli, Adèle Dumilâtre, Tamara Karsavina, Moira Shearer, and Catherine Kerr.

"Illuminates the hidden dimensions of their emotional and psychological lives in [Eliot's] focus on developments in ballet and modern dance since the eighteenth century."

-Janice Ross, author of Anna Halprin: Experience as Dance Illus. Cloth $\$ 32.95$

\section{www.press.uillinois.edu $\cdot 800-621-2736$}




\title{
UNIVERSITY OF ILLINOIS PRESS
}

\author{
Ballroom, Boogie, Shimmy Sham, Shake \\ A Social and Popular \\ Dance Reoder
}

Edited by JULIE MALNIG

"This invaluable volume covers an impressive range of genres, illuminating the liveliness and diversity of social dance. . . .

An excellent book and a godsend for classroom use." - Tricia

Henry Young, director of the graduate program in American dance studies, Florida State University

Illus. Cloth \$75.00; Paper $\$ 25.00$
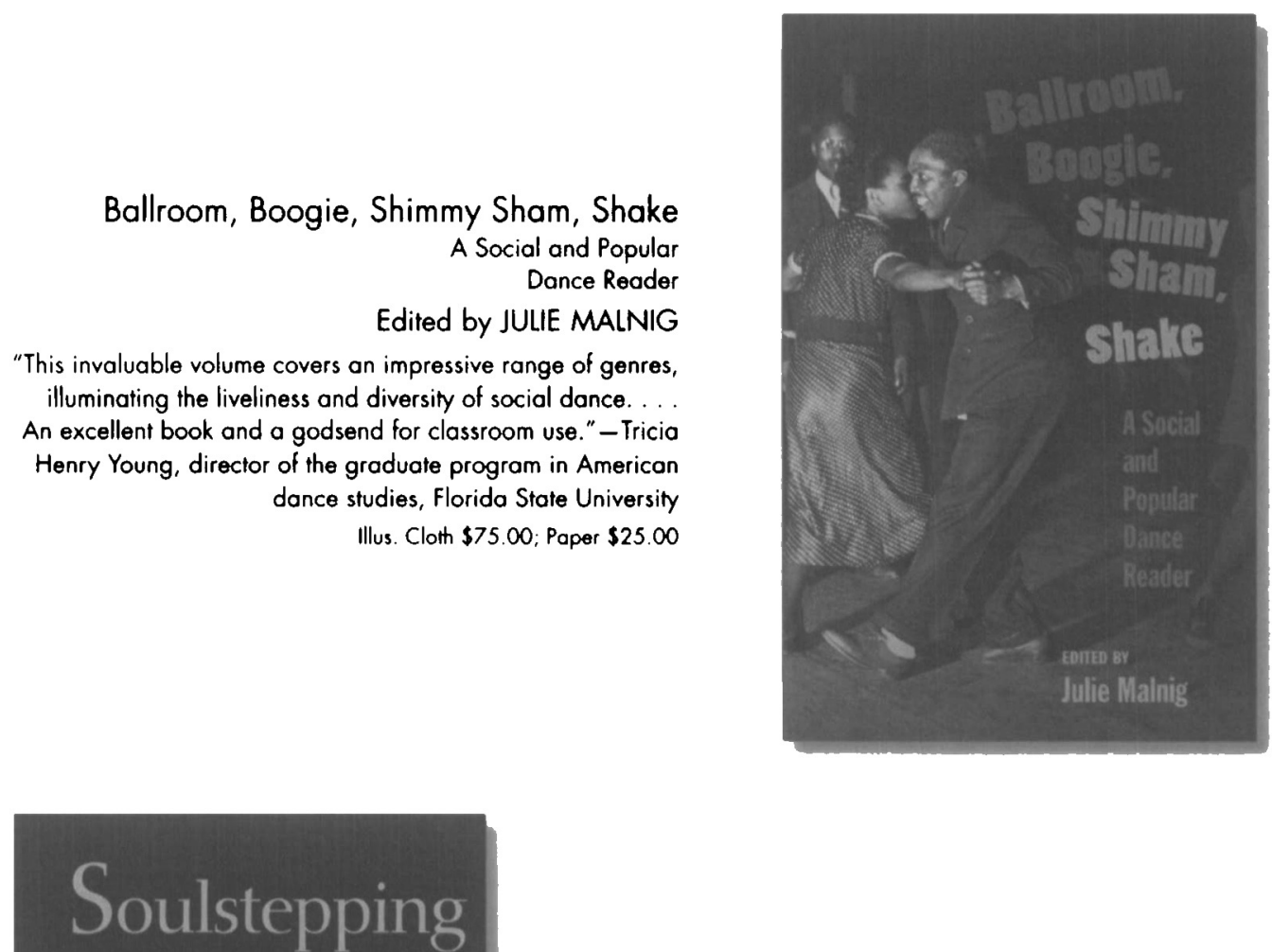

AFRICAN

AMERICAN

STEP

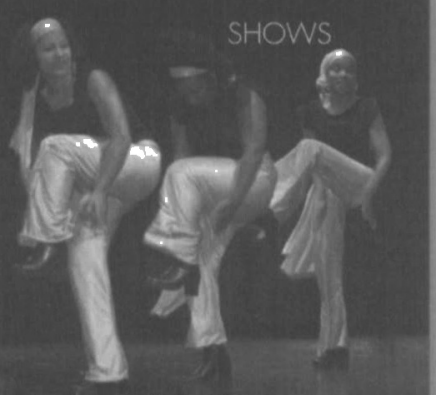

ELIZABETH C. FINE

\section{Soulstepping \\ African American Step Shows \\ ELIZABETH C. FINE}

"Elizabeth Fine takes us on a journey of discovery. . . All groups have dance steps that the group performs together for the pure joy of celebrating life. Soulstepping brings out that joy, that exhilaration, that love of life. This celebration is long overdue." - Nikki Giovanni

Illus. New in Paper \$19.95

\section{www.press.uillinois.edu $\cdot 800-621-2736$}




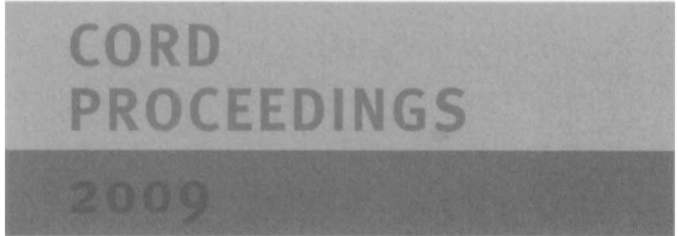

https://doi.org/10.1017/S2049125500000807 Published online by Cambridge University Press 
CORD BOARD OF DIRECTORS EXECUTIVE COMMITTEE

PRESIOENT: Barbara Sellers-Young

PAST-PRESIDENT: Ray Miller

recording Secretary: Candace Feck

Treasurer: Carla Huntington

editorial board ChaIR: Michael Huxley

BOARD OF DIRECTORS

Patrick Alcedo

Ananya Chatterjea

Maura Keefe

Hari Krishnan

SanSan Kwan

Frederick John Lamp

Juliet McMains

Norton Owen

Claire Rousier

Karen Schaffman

Karen Vedel

Graduate Student Representative: Clare Croft

EDITORIAL BOARD

Mark Franko, Dance Research Journal Editor

Rebekah Kowal, DRJ Book Reviews Editor

Tresa Randall, Proceedings Editor

Ann Dils

Tricia Henry Young

OFFICE ADMINISTRATOR

Ashanti Pretlow, Prime Management Systems Executive Director

NATIONAL OFFICE

All inquiries regarding membership, publications, and future conferences should be directed to:

Congress on Research in Dance

3416 Primm Lane

Birmingham, AL 35216

Phone: (205) 823-55 17

Fax: (205) 823-2760

Website: www.cordance.org 
